\title{
The Circassian Genocide
}




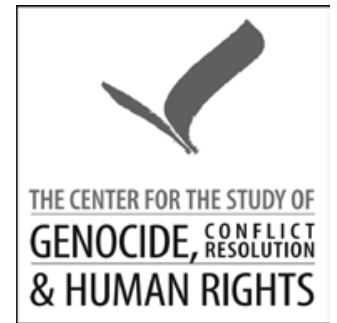

Genocide, Political Violence, Human Rights Series

Edited by Alexander Laban Hinton, Stephen Eric Bronner, and Nela Navarro

Alan W. Clarke, Rendition to Torture
Lawrence Davidson, Cultural Genocide

Alexander Laban Hinton, ed., Transitional Justice: Global Mechanisms and Local Realities after Genocide and Mass Violence

Irina Silber, Everyday Revolutionaries: Gender, Violence, and Disillusionment in Postwar El Salvador

Samuel Totten and Rafiki Ubaldo, eds., We Cannot Forget: Interviews with Survivors of the 1994 Genocide in Rwanda

Ronnie Yimsut, Facing the Khmer Rouge: A Cambodian Journey 


\section{The Circassian Genocide}

WALTER RICHMOND

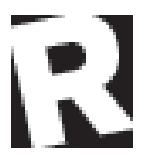

RUTGERS UNIVERSITY PRESS

NEW BRUNSWICK, NEW JERSEY, AND LONDON 


\section{Library of Congress Cataloging-in-Publication Data}

Richmond, Walter.

The Circassian genocide / Walter Richmond.

pages $\mathrm{cm}$. - (Genocide, political violence, human rights series)

Includes bibliographical references and index.

ISBN 978-0-8135-6068-7 (hardcover : alkaline paper) - ISBN

978-0-8135-6067-0 (paperback : alkaline paper) - ISBN 978-0-8135-6069-4 (e-book)

1. Circassians-Russia (Federation)—Caucasus, Northern-History. 2. RussiaRelations-Russia (Federation)—Caucasus, Northern. 3. Caucasus, Northern (Russia)-Relations-Russia. 4. Genocide-Russia (Federation)-Caucasus, Northern-History. I. Title. II. Series: Genocide, political violence, human rights series.

DK34.C57R53 2013

947.08'1—dc23

2012023501

A British Cataloging-in-Publication record for this book is available from the British Library.

Copyright $\odot 2013$ by Walter Richmond

All rights reserved

No part of this book may be reproduced or utilized in any form or by any means, electronic or mechanical, or by any information storage and retrieval system, without written permission from the publisher. Please contact Rutgers University Press, 106 Somerset Street, New Brunswick, NJ 08901. The only exception to this prohibition is "fair use" as defined by U.S. copyright law.

Visit our website: http://rutgerspress.rutgers.edu

Manufactured in the United States of America 
For my mother 
